\title{
FAKTOR PENENTU BERTEMPAT TINGGAL PADA KAWASAN KUMUH DI KOTA MALANG BERDASARKAN TEORI DOXIADIS
}

\author{
Key Reason For Settled On Slum Area In Malang City \\ Based On Doxiadis Theory
}

\section{Endratno Budi Santosa ${ }^{1}$, Ledy Vithalia Therik}

Diterima: 26 Juli 2016 Disetujui: 10 Oktober 2016

\begin{abstract}
Abstraksi: Kesinambungan sebuah permukiman sangat bergantung pada bagaimana persepsi manusia yang tinggal di dalamnya, apalagi jika kawasan permukiman yang dihuni termasuk katagori kumuh. Kondisi permukiman di Jodipan banyak dipengaruhi oleh berbagai faktor, salah satu yang jadi acuan adalah aspek ekistik, yang dirumuskan oleh Doxiadis. Penelitian ini bertujuan untuk mengkaji faktor penentu bertempat tinggal pada lokasi studi, dan memiliki sasaran untuk menemukenali keberadaan 5 aspek ekistik di Permukiman Kumuh Jodipan Kota Malang, serta mengetahui persepsi penghuni mengenai aspek ekistik apa yang paling mempengaruhi mereka dalam bertempat tinggal di lokasi studi. Penelitian dilakukan dengan menggunakan pendekatan survei primer-sekunder, termasuk observasi dan penyebaran kuisioner pada 2 RW yang dianggap prioritas. Pengolahan data dibantu dengan skema skala likert, serta analisis regresi berganda beserta beberapa perangkat pelengkapnya, seperti uji multikolonieritas, uji T, dan Uji F. Berdasarkan kajian, dapat disimpulkan bahwa elemen eksitik yang paling mempengaruhi penghuni permukiman kumuh untuk bertempat tinggal adalah adanya aspek bangunan (shell).
\end{abstract}

Kata Kunci: Faktor Penentu Bertempat Tinggal, Ekistik, Doxiadis, Regresi Berganda, Jodipan Kota Malang

\begin{abstract}
The sustainability process of a human settlement depend on how the perception of its people. Jodipan condition, as a slum area in Malang City, influenced by several factors, one factor named ekistic factor as in Doxiadis theory. This research's aim is to analyze key factor for the resident to stay, and tries to identify how this ekistic factor related and influenced with people perception in choosing settlement location. This research run by primary and secondary survey, and also helps by observation and questionnaire distribution at two priority location. By using likert scale approach and multiple regression analysis, this research also using some of statistical test, such as T Test, F Test, and multicolonierity test. After analysis process, this research found that shell variable (such as building of the house) as the main reason for the resident to stay at Jodipan slum.
\end{abstract}

Key words: reason to stay, ecistic factor, doxiadis, multiple regression, Jodipan Malang City

\footnotetext{
${ }^{1}$ Laboratorium Kota Kultural, PS. Perencanaan Wilayah dan Kota, Institut Teknologi Nasional Malang
}

Korespondensi: arsenal_end@yahoo.co.id atau endratnobudi@gmail.com 
Permukiman merupakan suatu lingkungan tempat tinggal yang lebih dari sekedar rumah atau perumahan yang mengandung keterpaduan kepentingan dan keselarasan pemanfaatan sebagai lingkungan kehidupan (Sadana, 2014). Di dalam permukiman dikenal juga dengan istilah ekistics- yaitu istilah Yunani yang dipakai untuk menjelaskan pengetahuan mengenai permukiman. Istilah permukiman dipakai sebagai padanan kata Human Settlements. Jadi, permukiman diartikan sebagai tempat manusia hidup dan berkehidupan (Winarso, 2013). Salah satu masalah di permukiman perkotaan pada umumnya adalah mengenai permukiman kumuh atau kawasan permukiman kumuh di perkotaan.

Kota Malang merupakan salah satu kota di Jawa Timur yang memiliki kawasan permukiman kumuh sebagai salah satu permasalahan di kawasan perkotaan. Permukiman di Kota Malang tersebar di seluruh wilayah kota. Konsentrasi permukiman berada di pusat kota dengan pola perkembangan yang cenderung mengikuti struktur jaringan jalan. Permukiman di Kota Malang dibagi ke dalam 7 (tujuh) karakteristik, yaitu kawasan permukiman kolonial belanda, kawasan permukiman kampung, kawasan real estate (kapling kecil, sedang, besar), kawasan perumahan di wilayah hinterland, kawasan rumah susun, kawasan permukiman militer, dan kawasan permukiman kumuh.

Permukiman kumuh merupakan permasalahan klasik yang sejak lama telah berkembang di kota-kota besar. Walaupun demikian, permasalahan permukiman kumuh tetap menjadi masalah dan hambatan utama bagi pengembangan kota. Laju perkembangan kota yang semakin pesat membuat pemanfaatan lahan yang semakin kompetitif, sedangkan di sisi lain, perkembangan kota menjadi daya tarik urbanisasi yang pada akhirnya menyebabkan tingginya tingkat permintaan akan tempat tinggal di dalam kota. Selain itu pesatnya perkembangan penduduk perkotaan tersebut yang umumnya berasal dari urbanisasi tidak selalu dapat diimbangi oleh kemampuan pelayanan kota sehingga telah berakibat pada semakin meluasnya lingkungan permukiman kumuh.

Permukiman kumuh umumnya memiliki tingkat kepadatan bangunan dan penduduk yang lebih tinggi dari kampung biasa dan berlokasi di Sepanjang aliran Sungai Brantas, sekitar rel kereta api, dan juga pada beberapa kawasan kampung lainnya. Pada umumnya kondisi bangunan pada permukiman kumuh di Kota Malang adalah permanen, hanya beberapa bagian saja yang terbuat dari bahan semi permanen (PU Kota Malang, 2014). Permukiman kawasan kumuh kelurahan Jodipan termasuk ke dalam kategori kumuh sedang, dengan permasalahan utama kawasan kumuh ini adalah kondisi Fisik Hunian, Sanitasi, Drainase, Kepadatan Penduduk, Kepadatan Bangunan.

Adanya kawasan permukiman kumuh, merupakan satu bentuk atau gambaran kegagalan didalam menyediakan rumah yang layak bagi seluruh golongan penduduk. Munculnya permukiman kumuh di Kelurahan Jodipan yang sebagian kawasannya adalah bantaran Sungai Brantas tentunya tidak lepas dari penurunan kualitas air sungai akibat aktivitas penduduk sekitar. Penduduk di Kelurahan Jodipan yang bertempat tinggal tepat pada sekitar bantaran Sungai Brantas cenderung memanfaatkan sungai untuk memenuhi kebutuhan sehari-hari seperti mandi, cuci dan kakus tanpa melalui sanitasi pembuangan limbah rumah tangga yang teratur.

Menurut data kawasan kumuh Kota Malang 2014, Kelurahan Jodipan di Kecamatan Blimbing Kota Malang termasuk kedalam kawasan kumuh berat dengan jumlah 2 (dua) RW ditetapkan sebagai kawasan yang diprioritaskan tingkat kekumuhannya yaitu RW 6 dan RW 7 dengan luas 4,8 Ha dikategorikan bentukan spasialnya yaitu scattered (tersebar). Oleh sebab itu lokasi penelitian lebih difokuskan pada 2 RW yaitu RW 6 dan RW 7 Kelurahan Jodipan.

Penelitian ini bertujuan untuk mengidentifikasi prinsip-prinsip permukiman yang dirumuskan oleh Constantinos Doxiadis (1968) dengan kondisi di lapangan yaitu kawasan permukiman kumuh di kelurahan Jodipan Kecamatan Blimbing Kota Malang. Ada lima 
elemen dasar permukiman yang dirumuskan oleh Constantinos Doxiadis (1968), yaitu : Nature (alam), Man (manusia) baik pribadi maupun kelompok, Society (Masyarakat), Shells (rumah) atau bangunan, Networks (jaringan atau sarana prasarana) yaitu jaringan yang mendukung fungsi permukiman baik alami maupun buatan manusia seperti jalan lingkungan, pengadaan air bersih, listrik, drainase, dan lain-lain. Untuk mewujudkan tujuan tersebut, maka sasaran yang harus dicapai, adalah : (1) Mengidentifikasi elemen Alam (nature), elemen Manusia (man), elemen Masyarakat (society), elemen Bangunan (shells), elemen Jaringan Sarana dan Prasarana (network) pada permukiman kumuh di Kelurahan Jodipan Kota Malang. (2). Merumuskan elemen Ekistik yang paling mempengaruhi pada kondisi permukiman kumuh di Kelurahan Jodipan Kota Malang.

Tujuan penelitian ini menjadi penting karena dengan diketahuinya variable yang paling mempengaruhi orang/ penghuni untuk bertempat tinggal, maka bisa menjadi masukan untuk perumusan startegi penanganan yang paling tepat. Sebagai contoh merujuk pada penelitian oleh Sulestianson dan Indrajati (2014) mengenai perumusan strategi pengentasan permukiman kumuh berbasis pada factor penyebabnya, yang beberapa hasilnya adalah mengenai aspek kestrategisan lokasi, lengkapnya fasilitas, kedekatan lokasi kerja sebagai beberapa alas an utama warga bertempat tinggal, dan model slum upgrading dilanjutkan dengan konsolidasi lahan (perkotaan) sebagai model penanganan yang dianggap paling cocok.

\section{METODE}

\section{Metode Pengumpulan Data.}

Dalam penelitian ini dilakukan pengumpulan data terhadap obyek yang diteliti dalam rangka mendapatkan gambaran mengenai suatu keadaan atau permasalahan di kawasan penelitian. Adapun teknik pengumpulan data yang digunakan dalam penelitian ini antar lain:

\section{Observasi atau Pengamatan Langsung}

Observasi dalam penelitian ini dilakukan pada variabel-variabel yakni iklim, geologi, topografi, tanah, air, tumbuh-tumbuhan, hewan, kebutuhan biologi (ruang, udara, air, suhu,dll), nilai moral dan budaya, kepadatan penduduk, strata sosial, budaya, ekonomi, pendidikan, kesehatan dan kesejahteraan (hiburan), hukum, rumah, fasilitas umum (sekolah, rumah sakit, perdagangan, dll), pusat perbelanjaan dan pasar, tempat rekreasi, perkantoran, industri, transportasi, jaringan (sistim air bersih, listrik, jalan, telepon, TV), sarana transportasi, jaringan (drainase, sampah, dan MCK), tata letak fisik.

\section{Kuesioner}

Kuesioner dalam penelitian ini yaitu mencakup variabel-variabel penelitian yakni mengenai lima elemen ekistik yang mempengaruhi permukiman kumuh. Penyebaran kuesioner dilakukan terhadap sampel yang merupakan obyek dari penelitian, yaitu masyarakat yang tinggal di kawasan permukiman kumuh kelurahan Jodipan Kota Malang. Untuk menentukan jumlah sampel digunakan teknik sampling yaitu merupakan teknik pengambilan sampel (Sugiono, 2010). Penyebaran kuisioner dilakukan dengan cara mengambil beberapa sampel yang dapat dihitung dengan menggunakan rumus Slovin yaitu sebagai berikut:

Keterangan:

$\mathrm{n}=$ Jumlah sampel

$\mathrm{N}=$ Jumlah populasi

$$
n=\frac{\mathrm{N}}{1+\mathrm{N}(\mathrm{d})^{2}}
$$


$\mathrm{d}=$ Nilai presisi

Jumlah populasi (N) yang digunakan adalah Jumlah Kepala Keluarga yang ada di lokasi studi yaitu kelurahan Jodipan Kecamatan Blimbing Kota Malang,akan tetapi yang dipilih hanyalah $542 \mathrm{KK}$ (Anonim, 2014) yang merupakan jumlah penduduk miskin yang ada di Keluarahan Jodipan. Nilai presisi ditetapkan 10\% dengan tingkat kepercayaan 95\%. Berdasarkan rumus tersebut maka perhitungan sampel dilakukan sebagai berikut:

Diketahui : $\mathrm{N}=542$

$\mathrm{D}=10 \%=0,1$

Jumlah sampel yang diperoleh adalah :

$n=\frac{\mathrm{N}}{1+\mathrm{N}(\mathrm{d})^{2}}$

$n=\frac{542}{1+542(0,1)^{2}}$

$n=\frac{542}{6,42}=84,4=84$

Jadi, hasil yang diperoleh untuk menentukan jumlah sampel yaitu: 84 sampel.

Konsep perhitungan yang sama juga pernah disampaikan oleh Fitria dan Setiawan (2014) dalam mengkalkulasi tingkat kekumuhan di Jakarta Barat, yang salah satu kesimpulannya memperlihatkan adanya perbedaan factor yang berpengaruh pada beberapa kelas permukiman kumuh (berat, sedang, ringan). Beberapa variable berpengaruh terhadap kondisi permukiman kumuh kelas berat yang dianggap signifikan adalah keberadaan saranaprasarana, tingkat pendidikan dan pendapatan/ekonomi penghuni, serta aspek kerawanan bencana.

\section{Sasaran Populasi}

Sugiyono (2010) menyatakan bahwa populasi adalah wilayah generalisasi yang terdiri atas obyek/subyek yang mempunyai kualitas dan karakteristik tertentu yang ditetapkan oleh peneliti untuk dipelajari dan kemudian ditarik kesimpulannya. Jadi populasi bukan hanya orang tetapi juga obyek dan benda-benda alam yang lain. Populasi dalam penelitian ini adalah semua masyarakat yang berada di kawasan permukiman kumuh Kelurahan Jodipan Kecamatan Blimbing Kota Malang.

Permukiman kawasan kumuh kelurahan Jodipan termasuk ke dalam kategori kumuh sedang, dengan permasalahan utama kawasan kumuh ini adalah kondisi Fisik Hunian, Sanitasi, Drainase, Kepadatan Penduduk, Kepadatan Bangunan (Anonim, 2014). Dalam profil wilayah kelurahan Jodipan Kecamatan Blimbing Kota Malang tahun 2015, luas wilayah Kelurahan Jodipan mencakup 49,35 Ha dengan jumlah penduduk 13.368 jiwa, 2.337 KK (Kepala Keluarga) yang terbagi atas 542 KK (Kepala Keluarga) jumlah penduduk miskin (Anonim, 2015). Oleh sebab itu, sampel yang diambil dalam penelitian yaitu 84 jumlah sampel akan disebarkan ke 2 RW dengan jumlah 542 KK (Kepala Keluarga) yang dikategorikan kawasan kumuh berat. 


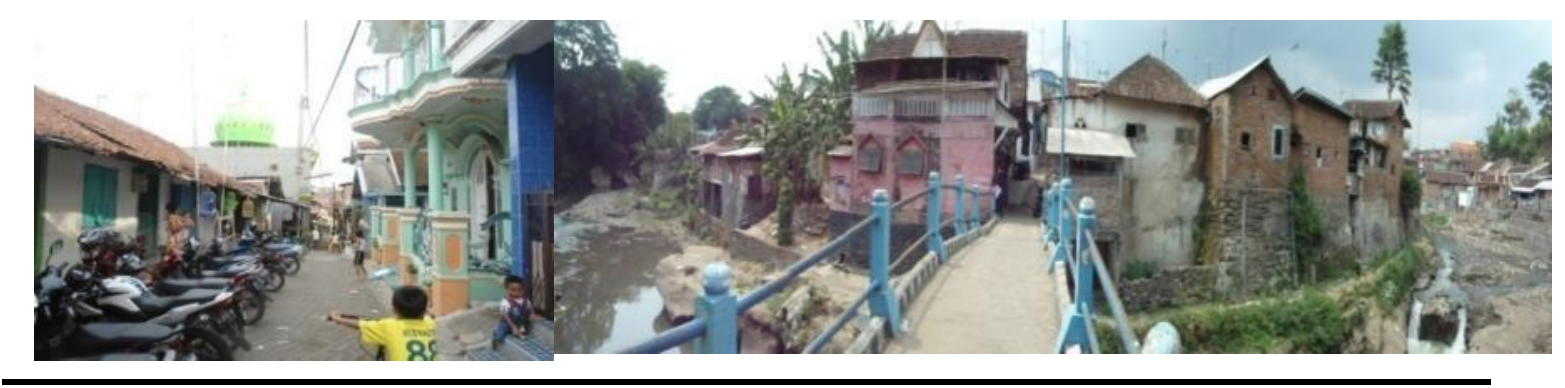

Gambar 1. Kondisi Permukiman di Lokasi

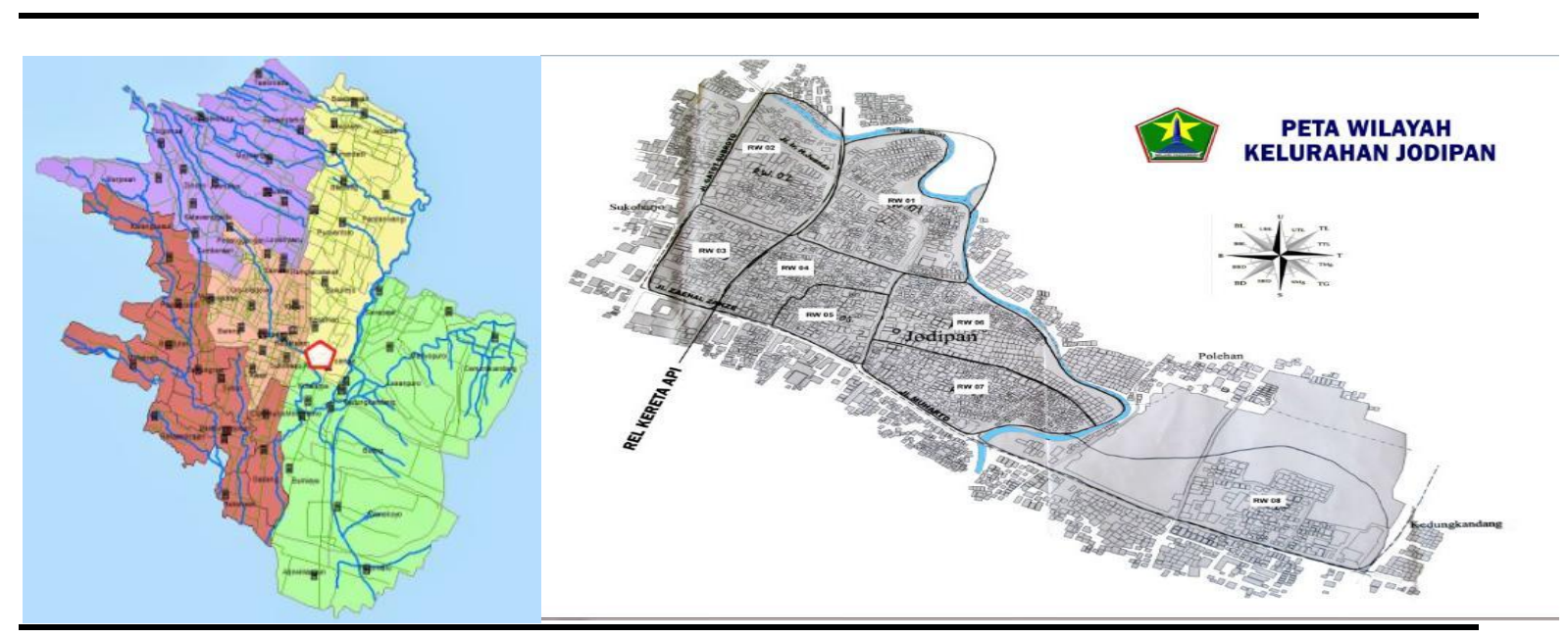

Gambar 2. Peta Wilayah Penelitian

\section{Teknik Analisis}

Teknik analisis data yang akan dipergunakan dalam penelitian ini adalah statistic kuantitatif. Teknik analisis yang dipergunakan dalam penelitian ini menggunakan analisis regresi. Teknik analisis yang digunakan dapat dijelaskan sebagai berikut :

\section{Skala Pengukuran}

Skala likert adalah skala psikometrik yang digunakan untuk mengukur sikap, pendapat, dan persepsi seseorang atau sekelompok orang tentang fenomena sosial. Skala likert umumnya digunakan dalam kuesioner dan riset berupa survei, terutama penelitian survei deskriptif. Maka dapat disimpulkan bahwa penggunaan skala likert merupakan alat untuk mengukur (mengumpulkan data dengan cara "mengukur-menimbang") persepsi seseorang atau sekelompok orang tentang fenomena sosial yang butir-butir pertanyaannya berisikan pilihan yang berjenjang. Jawaban setiap item instrument mempunyai gradasi dari yang sangat positif hingga sangat negatif.

\section{Teknik analisis regresi}

Pengertian regresi secara umum adalah sebuah alat statistik yang memberikan penjelasan tentang pola hubungan (model) antara dua variabel atau lebih. Dalam penelitian ini, digunakan analisis regresi berganda. Regresi berganda berguna untuk mencari pengaruh dua atu lebih variabel bebas atau untuk mencari hubungan fungsional dua variabel bebas 
atau lebih terhadap variabel terikatnya, atau untuk meramalkan dua variabel bebas atau lebih terhadap variabel terikatnya. Regresi linear berganda adalah regresi linear dimana variabel terikatnya (variabel Y) dihubungkan dengan dua atau lebih variabel bebas (variabel X). penambahan variabel bebas ini diharapkan dapat lebih menjelaskan karakteristik hubungan yang ada, walaupun masih saja ada variabel yang terabaikan. Persamaan regresi linear berganda dapat dituliskan sebagai berikut (Misbahudin, 2004):

$$
Y=\alpha+b_{1} X_{1}+b_{2} X_{2}+b_{3} X_{3}+b_{4} X_{4}+
$$

$\begin{array}{lll}\text { Keterangan: } & & \\ \mathrm{Y} & = & \text { variabel terikat (nilai duga Y) } \\ X_{1} X_{2} X_{3} X_{4} X_{5} & = & \text { variabel bebas } \\ \alpha, b_{1} b_{2} b_{3} b_{4} b_{5} & = & \text { koefisien regresi linear berganda } \\ \text { a } & = & \text { nilai Y, jika } X_{1}=X_{2}=X_{3}=X_{4}=X_{5}=0 \\ b_{3} b_{4} b_{5} & = & \text { besarnya satuan kenaikan atau penurunan Y dalam satuan, jika X ke-n, } \\ b_{2} b_{3} b_{4} b_{5} & = & \text { naik/turun satu satunya X lainnya konstan. } \\ & \text { disebut juga koefisien regresi parsial (partial coefficient regression). }\end{array}$

\section{Uji Statistik Regresi Linear Berganda}

Uji statistik regresi linear berganda digunakan untuk menguji signifikan atau tidaknya hubungan dua variabel melalui koefisien regresinya. Dalam penelitian ini digunakan Uji kelayakan model dalam regresi linear berganda. Terdapat dua uji statistik yaitu Uji keterandalan model atau biasa dikenal Uji F dan Uji Koefisien regresi atau biasa dikenal Uji $\mathrm{T}$.

\section{Analisis Regresi Linear Berganda}

Regresi linear berganda adalah regresi linear dimana variabel terikatnya (variabel Y) dihubungkan dengan dua atau lebih variabel bebas (variabel X). penambahan variabel bebas ini diharapkan dapat lebih menjelaskan karakteristik hubungan yang ada, walaupun masih saja ada variabel yang terabaikan.

Dalam analisis ini, untuk mencari elemen ekistik yang paling mempengaruhi kondisi permukiman kumuh Kelurahan Jodipan Kota Malang, terlebih dahulu harus ditentukan nila $\mathrm{X}$ dan nilai $\mathrm{Y}$.

\section{PEMBAHASAN}

Di dalam buku EKISTICS An introduction to the science of human settlement yang ditulis oleh Constantinos A. Doxiadis (1968), Permukiman adalah tempat manusia hidup dan berkehidupan. Oleh karenanya, suatu permukiman terdiri atas the content (isi) yaitu manusia dan the container (tempat fisik manusia tinggal yang meliputi elemen alam dan buatan manusia). Dalam pengertian ini, Doxiadis mengatakan, permukiman tidak hanya digambarkan dalam tiga demensi saja, tetapi harus empat dimensi, oleh karena ada unsure manusia yang hidup dan selalu berubah karakter dan budayanya dalam kerangka waktu.

Ekistics dikembangkan dengan memperhatikan dan menganalogikan permukiman dengan biologi. Doxiadis mengatakan, "There can be no doubt, I think, that human settlements are very complex biological individuals. Human settlements can be neither cells nor bodies nor organisms. We are, therefore, entitled to consider them as biological individuals of a higher order than cells or organisms" (Doxiadis, 1968).

Doxiadis (1968) merumuskan ada lima elemen dasar permukiman, yaitu (Winarso, 2013):

1. Elemen Alam (nature), yang meliputi: iklim, geologi, topografi, tanah, air, tumbuhtumbuhan, dan hewan. 
2. Elemen Manusia (man), yang meliputi: kebutuhan biologi (ruang, udara, air, suhu,dll), sensasi dan persepsi (rasa), kebutuhan emosi (hubungan manusia, keamanan, keindahan, dll), nilai moral dan budaya.

3. Elemen Masyarakat (society), yang meliputi: kepadatan penduduk, strata sosial, budaya, ekonomi, pendidikan,kesehatan dan kesejahteraan (hiburan), dan hukum.

4. Elemen Bangunan (shells), yaitu meliputi: rumah, fasilitas umum (sekolah, rumah sakit, perdagangan, dll), pusat perbelanjaan dan pasar, tempat rekreasi, perkantoran, industri, dan transportasi.

5. Elemen Sarana prasarana (network), yang meliputi: jaringan (sistim air bersih, listrik, jalan, telepon, TV), sarana transportasi, jaringan (drainase, sampah, dan $\mathrm{MCK})$, dan tata letak fisik.

Ada beberapa penelitian yang menggunakan dasar teori yang sama, walau dengan menggunakan pendekatan yang berbeda, misalkan saja yang dilakukan Anggraeni dkk (2014) pada kasus permukiman di Bantaran Bengawan Solo di Kabupaten Bojonegoro. Penelitian yang menggunakan metode SEM (Sequential Equation Models) bertujuan untuk mencari alasan warga untuk tetap bertahan bertempat tinggal di area langganan banjir, yang hasilnya menyimpulkan bahwa aspek/ variabel shellmenjadi alasan utama bagi warga untuk tetap tinggal. Berdasarkan sisi yang berbeda, produktivitas (ekonomi) warga, keberadaan key stakeholder termasuk perbankan, serta pemanfaatan teknologi menjadi beberapa factor kunci yang bisa membuat sebuah permukiman bisa bertahan, seperti yang dikemukakan oleh Atika, Faqih dan Rachmawati (2015) dalam penelitian di Kabupaten Gresik.

\section{KONDISI LOKASI PENELITIAN}

\section{Elemen Alam}

Kelurahan Jodipan di Kecamatan Blimbing Kota Malang berada pada ketinggian 440 667 meter di atas permukaan laut. Dari pola yang tergambar selama tahun 2014 suhu ratarata selama bulan Januari sampai September cenderung lebih tinggi dibanding pada tahun 2013. Sedangkan pada bulan Oktober sampai Desember lebih rendah dibanding tahun 2013. Kondisi iklim Kota Malang selama tahun 2014 tercatat rata-rata suhu udara berkisar antara $22,0^{\circ} \mathrm{C}$ sampai $24,8^{\circ} \mathrm{C}$. Sedangkan suhu maksimum mencapai $31,4^{\circ} \mathrm{C}$ dan suhu minimum $17,2^{\circ} \mathrm{C}$. Rata-rata kelembaban udara berkisar $66 \%-83 \%$, dengan kelembaban maksimum $98 \%$ dan minimum mencapai $19 \%$.

Topografi atau kelerengan wilayah penelitian yaitu RW 6 dan RW 7 Kelurahan Jodipan Kota Malang memiliki dua kelas kelerengan yaitu kelas $0-3 \%$ dan kelas $15-25 \%$. Tekstur tanah pada lokasi penelitian yaitu RW 6 dan RW 7 Kelurahan Jodipan Kota Malang pada umumnya yaitu tekstur halus liat, sedangkan untuk jenis tanah pada lokasi penelitian yaitu RW 6 dan RW 7 Kelurahan Jodipan Kota Malang yaitu jenis tanah alluvial dan latosol.

Data yang diperoleh dengan melakukan survey lapangan dan penyebaran kuesioner, Keadaan tempat tumbuh tumbuhan pada lokasi penelitian yaitu RW 6 dan RW 7 Kelurahan Jodipan Kecamatan Blimbing Kota Malang dapat dikategorikan dalam kondisi baik, karena 67\% responden menjawab kondisi tempat tumbuh tumbuhan di RW 6 dan RW 7 dikategorikan baik. tempat tumbuh tumbuhan yaitu seperti tanaman bunga ditempatkan pada tempat yang selayaknya untuk tanaman yaitu dalam pot bunga atau sejenis bedeng tanaman. 


\section{Elemen Manusia}

Secara keseluruhan dari hasil survey secara primer dan secara sekunder, lokasi penelitian yaitu khususnya pada RW 6 dan RW 7 Kelurahan Jodipan Kota Malang, kebutuhan manusia yang tinggal di lokasi penelitian, secara biologi yaitu mencakup kebutuhan ruang, udara, suhu, dsb, peneliti kaji dengan melihat beberapa aspek di lingkungan masyarakat yaitu mengenai ketertiban kehidupan bermasyarakat di lingkungan sekitar, keamanan tinggal di lingkungan sekitar, kerukunan antar sesama manusia di lingkungan sekitar, kenyamanan bersosialisasi antar sesama manusia di lingkungan sekitar.

Secara keseluruhan dari hasil survey secara primer, lokasi penelitian yaitu khususnya pada RW 6 dan RW 7 Kelurahan Jodipan Kota Malang, kebutuhan manusia dalam hal ini yaitu mengenai sensasi dan persepsi (rasa) dikategorikan cukup terpenuhi karena dengan banyak manusia yang mengakui bahwa sudah nyaman tinggal dilokasi tersebut dan bahkan ada yang sudah dari lahir dan tinggal menetap di lokasi ini.

Kebutuhan emosi dalam hal ini yang dapat dikaji adalah mengenai hubungan manusia yang bertempat tinggal di lokasi penelitian, keamanan yang ada pada lokasi penelitian, keindahan lokasi penelitian, dsb. Secara keseluruhan dari hasil survey secara primer, lokasi penelitian yaitu khususnya pada RW 6 dan RW 7 Kelurahan Jodipan Kota Malang, kebutuhan emosi dapat dikatakan masih belum mencukupi karena masih ada permasalahan sosial yang terdapat di masyarakat, contohnya keamanan yang masih kurang, keindahan lingkungan yang jarang dirasakan bagi manusia yang tinggal di lokasi penelitian dikarenakan lokasi penelitian termasuk ke dalam lokasi permukiman kumuh.

Lokasi penelitian yaitu khususnya pada RW 6 dan RW 7 Kelurahan Jodipan Kota Malang, peneliti mengkaji mengenai nilai moral dan budaya manusia yang tinggal dilokasi penelitian yaitu dengan melihat secara langsung pola perilaku manusia secara umum dilokasi penelitian pada saat survey primer dilakukan dan dengan mengkaji lewat kuesioner yang dibagikan kepada responden. Untuk lebih jelasnya mengenai nilai moral dan budaya manusia di lokasi penelitian dapat dijabarkan lebih lanjut pada sub bab hasil kuesioner elemen manusia.

\section{Elemen Masyarakat}

Kelurahan Jodipan Kecamatan Blimbing Kota Malang memiliki jumlah penduduk 13.368 Jiwa dengan 2.337 KK dan 542 KK penduduk miskin. Kepadatan penduduk Kelurahan Jodipan dikategorikan sangat padat dan kumuh dengan memiliki jumlah penduduk 269 jiwa/Ha (Anonim, 2014). Kepadatan penduduk juga mengakibatkan terjadinya kepadatan bangunan. Kepadatan bangunan pada dasarnya merupakan perbadingan antara jumlah bangunan yang ada pada suatu kawasan dengan luas kawasan tersebut. Suatu lingkungan permukiman menjadi kumuh salah satunya disebabkan oleh tingkat kepadatan bangunan yang tinggi akibat keterbatasan lahan yang tersedia.

Kelurahan Jodipan Kecamatan Blimbing Kota Malang memiliki penduduk dengan rata-rata bekerja sebagai pedagang. Menurut hasil survey primer dan sekunder, penduduk di lokasi penelitian yaitu RW 6 dan RW 7 Kelurahan Jodipan memiliki tingkat pendidikan terakhir yaitu Sekolah Dasar (SD) dan memiliki pekerjaan sebagai pedagang. Budaya masyarakat di Kelurahan Jodipan Kecamatan Blimbing Kota Malang, khususnya di lokasi survey RW 6 dan RW 7 dapat dikategorikan ke dalam masyarakat yang memiliki budaya hidup sehari-hari sudah cukup baik, masyarakat asli maupun masyarakat pendatang dapat menyesuaikan diri dengan lokasi tempat tinggal mereka yang walaupun dikategorikan permukiman kumuh.

Kondisi ekonomi masyarakat di Kelurahan Jodipan Kecamatan Blimbing Kota Malang, khususnya di lokasi survey RW 6 dan RW 7 yang bermata pencaharian pada umumnya adalah sebagai pedagang mendapatkan upah atau pendapatan rata-rata $\leq$ Rp. 1.000.000,- per 
bulan. Menurut hasil survey pada lokasi penelitian yaitu RW 6 dan RW 7, masyarakat di lokasi survey ini mengaku sudah cukup puas terlayani oleh fasilitas pendidikan yang ada. Kondisi fasilitas pendidikan di Kelurahan Jodipan dikategorikan baik dan sudah cukup melayani masyarakat yang berada disekitar fasilitas pendidikan tersebut. Fasilitas kesehatan yang dimiliki oleh Kelurahan Jodipan Kecamatan Blimbing Kota Malang yaitu hanya UKBM (Puskesmas pembantu) sejumlah 9 buah.

Secara keseluruhan dari hasil survey secara primer dan secara sekunder, lokasi penelitian yaitu khususnya pada RW 6 dan RW 7 Kelurahan Jodipan Kota Malang, masyarakat pada umumnya mencari hiburan ke pusat kota terdekat, yaitu kawasan pasar besar Kota Malang dan Alun-alun Kota Malang yang jaraknya $\pm 1 \mathrm{Km}$ dari tempat tinggal mereka.Kondisi hukum yang dapat dikaji dalam penelitian ini adalah wilayah atau sektor kepolisian terdekat yang dapat mengatasi atau melayani masyarakat jika terjadi segala ancaman bahaya atau segale permasalahan yang terjadi di masyarakat. Fasilitas hukum terdekat untuk wilayah lokasi survey penelitian ini yaitu khususnya masyarakat RW 6 dan RW 7 Kelurahan Jodipan Kota Malang yaitu Polres Sektor Blimbing dan Polres Kota Malang.

\section{Elemen Bangunan}

Elemen keempat yang akan dibahas dalam penelitian ini yaitu elemen bangunan. Beberapa hal yang termasuk dalam elemen bangunan yaitu antara lain rumah, fasilitas umum (sekolah, rumah sakit, perdagangan, dll), pusat perbelanjaan dan pasar, tempat rekreasi, perkantoran, industri, transportasi. Permukiman kumuh identik dengan kondisi dan kualitas bangunan yang minim dan tidak tertata dengan baik. Hal ini dapat dilihat dari banyaknya bangunan liar yang ada di sekitar kampung kumuh, tingkat kepadatan bangunan yang cukup tinggi. Semakin banyak rumah dalam suatu lingkungan permukiman yang tidak memenuhi kriteria kebutuhan minimal keselamatan dan keamanan mengindikasikan kondisi lingkungan permukiman semakin kumuh (PU Kota Malang, 2014). Kondisi bangunan yaitu rumah di lokasi penelitian khususnya masyarakat RW 6 dan RW 7 Kelurahan Jodipan Kota Malang, sesuai hasil survey primer, rata-rata rumah penduduk sudah permanen, akan tetapi masih ada juga penduduk yang memiliki rumah semi permanen.

Kondisi fasilitas umum yaitu fasilitas pendidikan, fasilitas kesehatan, fasilitas peribadatan, fasilitas perdagangan dan jasa di lokasi penelitian khususnya masyarakat RW 6 dan RW 7 Kelurahan Jodipan Kota Malang dikategorikan cukup baik karena sesuai hasil survey tidak adanya keluhan masyarakat mengenai fasilitas umum, hanya jarak tempuh yang cukup jauh untuk pergi ke puskesmas induk yang masih sering dikeluhkan kaum ibu-ibu di RW 6 dan RW 7. Masyarakat Kelurahan Jodipan Kota Malang khususnya masyarakat RW 6 dan RW 7 pada umumnya menggunakan jasa pusat perbelanjaan dan pasar yaitu pada pusat perbelanjaan pasar besar dan pasar comboran. Jarak yang cukup dekat untuk dijangkau dan kondisi pusat perbelanjaan dan pasar yang sudah cukup memenuhi kebutuhan masyarakat. Sesuai hasil survey primer mayarakat Kelurahan Jodipan Kota Malang khususnya masyarakat RW 6 dan RW 7 pada umumnya menggunakan Alun-alun kotak Kota Malang, Taman Trunojoyo stasiun Kota Malang, Alun-alun bundar Kota Malang sebagai tempat rekreasi terdekat untuk masyarakat dilokasi penelitian ini.

Jenis perkantoran yang dimiliki Kelurahan Jodipan adalah Kantor Kelurahan Pemerintah Kota Malang yaitu Kantor Kelurahan Jodipan. Sedang untuk perindustrian tidak dimiliki di lokasi penelitian ini. Sesuai hasil survey primer mayarakat Kelurahan Jodipan Kota Malang khususnya masyarakat RW 6 dan RW 7 pada umumnya menggunakan jasa transportasi yaitu mikrolet dan kadang menggunakan becak untuk bepergian dengan jarak dekat, sedangkan untuk jarak jauh menggunakan kendaraan pribadi yaitu sepeda motor. 


\section{Elemen Sarana dan Prasarana}

Sesuai hasil survey primer kondisi jaringan drainase, persampahan, dan MCK pada lokasi survey RW 6 dan RW 7 Kelurahan Jodipan Kota Malang pada umumnya dapat dikatakan buruk, hal ini karenakan jaringan drainase yang tidak baik bahkan ada rumah yang tidak memiliki drainase sebagai saluran air, jaringan sampah juga dikategorikan buruk karena masyarakat masih sering membuang sampah dikali, begitupun dengan MCK masyarakat masih minim perhatian untuk menggunakan fasilitas MCK dengan benar.

Tata letak fisik Kelurahan Jodipan Kota Malang khususnya pada wilayah lokasi survey RW 6 dan RW 7 Kelurahan Jodipan pada umumnya berada di daerah aliran sungai dengan wilayah kepadatan penduduk yang sangat tinggi dan kawasan permukiman yang tergolong dalam kawasan permukiman kumuh Kota Malang.

\section{Pengolahan Data Regresi Linear Berganda dengan SPSS}

Regresi Linier Berganda yang akan disimulasikan pada bagian ini menggunakan pendekatan Ordinary Least Squares (OLS). Penjelasan akan dibagi menjadi 5 tahapan, yaitu (Iqbal, 2012): 1) Persiapan Data (Tabulasi Data), 2) Estimasi Model Regresi Linier (Berganda), 3) Pengujian Asumsi Klasik, 4) Uji Kelayakan Model (Goodness of Fit Model) dan 5) Intepretasi Model Regresi Linier (Berganda)

\section{Pengujian Asumsi Klasik}

Pada tahap ini tidak dilakukan operasionalisasi software SPSS, melainkan hanya cara membaca uji asumsi klasik dari output SPSS, sebagaimana yang tertampil pada file OUTPUT. Untuk tahap ini akan dilakukan uji Multikolinieritas. Uji multikolinieritas bertujuan untuk menguji apakah dalam model regresi ditemukan adanya korelasi atau hubungan yang tinggi atau sempurna antar variabel independen. Jika antar variabel independen terjadi multikolinieritas sempurna, maka koefisien regresi variabel independen tidak dapat ditentukan dan nilai standard error menjadi tak terhingga. Jika multikolinieritas antar variabel independen tinggi, maka koefisien regresi variabel independen dapat ditentukan, tetapi memiliki nilai standard error tinggi berarti nilai koefisien regresi tidak dapat diestimasi dengan tepat (Nurmaida, 2011).

Nilai Tolerance-nya untuk variabel elemen alam (X1) adalah 0.916, variabel elemen bangunan (X4) adalah 0.949, variabel elemen sarana dan prasarana (X5) adalah 0.879, sedangkan Nilai VIF untuk variabel elemen alam (X1) adalah 1.091, variabel elemen mausia (X2) adalah 1.088, variabel elemen masyarakat (X3) adalah 1.131, variabel elemen bangunan (X4) adalah 1.053, variabel elemen sarana dan prasarana (X5) adalah 1.138. Karena nilai VIF dari kelima variabel tidak ada yang lebih besar dari 10 atau 5 (Peneliti menggunakan nilai presisi 10) maka dapat dikatakan tidak terjadi multikolinieritas pada kelima variabel bebas tersebut. Berdasarkan syarat asumsi klasik regresi linier, model regresi linier yang baik adalah yang terbebas dari adanya multikolinieritas. Dengan demikian data di atas telah terbebas dari adanya multikolinieritas. Atau dapat dikatakan kelima elemen ekistik ini tidak ditemukan adanya korelasi atau hubungan yang tinggi atau sempurna antar setiap variabel, berarti model regresi untuk penelitian ini layak dipakai.

\section{Uji Kelayakan Model}

Uji kelayakan model dalam regresi linear berganda terdapat dua uji statistik yaitu Uji keterandalan model atau biasa dikenal Uji F dan Uji Koefisien regresi atau biasa dikenal Uji T. untuk lebih jelasnya dapat dilihat pada penjabaran berikut: 


\section{Uji Keterandalan Model (Uji F)}

Uji keterandalan model atau uji kelayakan model atau yang lebih popular disebut sebagai uji $\mathrm{F}$ (ada juga yang menyebutnya sebagai uji simultan model) merupakan tahapan awal mengidentifikasi model regresi yang diestimasi layak atau tidak. Layak (andal) disini maksudnya adalah model yang diestimasi layak digunakan untuk menjelaskan pengaruh variabel-variabel bebas terhadap variabel terikat. Nama uji ini disebut sebagai uji F, karena mengikuti mengikut distribusi F yang kriteria pengujiannya seperti One Way Anova (Iqbal, 2012). Nilai prob. F hitung terlihat pada kolom terakhir (sig) dapat dijelaskan bahwa Nilai prob. F hitung (sig.) pada tabel nilainya 0.035 lebih kecil dari tingkat signifikansi 0.1 , sehingga dapat disimpulkan bahwa model regresi linier yang diestimasi layak digunakan untuk menjelaskan pengaruh elemen ekistik permukiman pada permukiman kumuh Kelurahan Jodipan.

\section{Uji Koefisien Regresi (Uji T)}

Uji t dalam regresi linier berganda dimaksudkan untuk menguji apakah parameter (koefisien regresi dan konstanta) yang diduga untuk mengestimasi persamaan/ model regresi linier berganda sudah merupakan parameter yang tepat atau belum. Seperti uji F yang dimudahkan dengan aplikasi SPSS, maka uji t juga dapat dengan mudah ditarik kesimpulannya. Apabila nilai prob. t hitung (ouput SPSS ditunjukkan pada kolom sig.) lebih kecil dari tingkat kesalahan (alpha) 0,1 (yang telah ditentukan) maka dapat dikatakan bahwa variabel bebas (dari t hitung tersebut) berpengaruh signifikan terhadap variabel terikatnya, sedangkan apabila nilai prob. $\mathrm{t}$ hitung lebih besar dari tingkat kesalahan 0,1 maka dapat dikatakan bahwa variabel bebas tidak berpengaruh signifikan terhadap variabel terikatnya.

Nilai prob. T hitung dari variabel bebas elemen alam (X1) sebesar 0,223 yang berarti lebih besar dari 0,1 sehingga variabel alam tidak berpengaruh signifikan terhadap kondisi permukiman kumuh (Y). variabel elemen manusia (X2) sebesar 0,411 yang berarti lebih besar dari 0,1 sehingga variabel manusia tidak berpengaruh signifikan terhadap kondisi permukiman kumuh $(\mathrm{Y})$. variabel elemen masyarakat $(\mathrm{X} 3)$ sebesar 0,895 yang berarti lebih besar dari 0,1 sehingga variabel masyarakat tidak berpengaruh signifikan terhadap kondisi permukiman kumuh (Y). variabel elemen bangunan (X4) sebesar 0,096 yang berarti lebih kecil dari 0,1 sehingga variabel bangunan berpengaruh signifikan terhadap kondisi permukiman kumuh (Y). variabel elemen sarana dan prasarana (X5) sebesar 0,260 yang berarti lebih besar dari 0,1 sehingga variabel sarana dan prasarana tidak berpengaruh signifikan terhadap kondisi permukiman kumuh $(\mathrm{Y})$.

\section{Intepretasi Model Regresi Linier (Berganda)}

Setelah estimasi model regresi linier berganda dilakukan dan diuji pemenuhan syaratnya (uji asumsi klasik) serta kelayakan modelnya, maka tahap terakhir adalah menginterpretasikannya. Interpretasi atau penafsiran atau penjelasan atas suatu model yang dihasilkan seharusnya dilakukan setelah semua tahapan (uji asumsi klasik dan kelayakan model) dilakukan.

Koefisien regresi untuk variabel alam yang adalah elemen alam (X1) bernilai sebesar 0.041 bernilai negatif artinya jika semakin buruk kondisi dan karakteristik alam pada Kelurahan Jodipan maka berpengaruh negatif pada kondisi permukiman kumuh menjadi semakin buruk mengikuti pegaruh dari elemen alam. Koefisien regresi elemen manusia (X2) bernilai sebesar $\quad-0.022$ bernilai negatif artinya jika semakin buruk atau SDM Kelurahan Jodipan semakin rendah maka akan berpengaruh negatif juga terhadap kondisi permukiman kumuh Kelurahan Jodipan. 
Etika berperilaku seseorang jika baik dan benar dalam lingkungan mereka tinggal akan berakibat dan berpengaruh baik dan benar pula pada lingkungan sekitar tempat tinggal mereka, begitupun sebaliknya. Koefisien regresi elemen masyarakat (X3) bernilai sebesar 0.004 bernilai negatif artinya semakin buruk atau semakin rendah kondisi dan karakter masyarakat di Kelurahan Jodipan akan akan berpengaruh negatif juga pada Kondisi permukiman kumuh di Kelurahan Jodipan.

Koefisien regresi elemen bangunan (X4) bernilai sebesar -0.039 bernilai negatif artinya semakin rendah atau semakin buruknya kondisi dan kualitas suatu bangunan di Kelurahan Jodipan dapat berpengaruh negatif juga pada kondisi permukiman kumuh. Koefisien regresi elemen sarana dan prasarana (X5) bernilai 0.031 bernilai positif yang artinya semakin baik kondisi dan karakteristik sarana dan prasarana di Kelurahan Jodipan akan berpengaruh baik juga pada kondisi permukiman kumuh Kelurahan Jodipan.

\section{KESIMPULAN}

Ada beberapa indikator yang peneliti kaji di dalam elemen bangunan yaitu antara lain rumah, fasilitas umum (sekolah, rumah sakit, perdagangan, dll), pusat perbelanjaan dan pasar, tempat rekreasi, perkantoran, industri, transportasi, dan hukum yang ada pada lokasi penelitian yaitu Kelurahan Jodipan Kecamatan Blimbing Kota Malang. Setelah melakukan identifikasi kelima elemen yaitu elemen alam, elemen manusia, elemen masyarakat, elemen bangunan, dan elemen sarana prasarana serta melakukan skala pengukuran dan analisis menggunakan metode regresi linear berganda, dapat disimpulkan hasil dari elemen ekistik yang paling mempengaruhi kondisi permukiman kumuh pada lokasi penelitian, yaitu RW 6 dan RW 7 adalah elemen bangunan, yang antara lain meliputi kondisi bangunan/ permukiman, beserta sarana-prasarana penunjang permukiman di lokasi studi.

\section{DAFTAR PUSTAKA}

Anggraeni, M., Ari, I.R., Santosa, E.B., 2014, Climate Change \& Home Location Preferences in Flood Prone Areas of Bojonegoro Regency: Social Network Approach , 2014, Procedia of Environmental Science, Vol. 20, ISSN: 1878-0296, pp.703-711, www.sciencedirect.com/science/article/pii/S1878029614000851

Atika, F.A, Fakih, m., Rahmawati, M., 2015, Sustainable Housing Development In Supporting Tourism of Sunan Giri Regions, International Journal of Education and Research, Vol. 3 No. 12 December 2015 dapat diunduh pada www.ijern.com/journal/2015/December-2015/26.pdf

Anonim, 2014, Profil Kecamatan Belimbing Kota Malang, Laporan tidak diterbitkan

Anonim, 2015, Profil Kelurahan Jodipan, Kecamatan Belimbing Kota Malang, Laporan tidak diterbitkan

Doxiadis, Constantinos, 1968, EKISTICS an Introduction to The Science of Human Settlement, London.

Fitria, N., dan Setiawan,P.R., 2014, Identifikasi Karakteristik Lingkungan Permukiman Kumuh di Kelurahan Kapuk, Jakarta Barat, JURNAL TEKNIK POMITS Vol. 3, No. 2, (2014) ISSN: 2337-3539, dapat diunduh pada ejurnal.its.ac.id/index.php/teknik/article/download/7290/1930

Iqbal, Muhammad. 2010. Pengolahan Data dengan Regresi Linear Berganda. (Dengan SPSS). Jakarta. STIE Perbanas Jakarta.

Iqbal, Muhammad. 2010. Pengolahan Data dengan Regresi Linear Berganda. (Dengan SPSS). Jakarta. STIE Perbanas Jakarta

Misbahuddin, Hasan Iqbal, 2004, Analisis Data Penelitian dengan Statistik, Jakarta. Bumi Aksara, Edisi ke-2.

Nurmaida, A.. 2011. Karakteristik Lingkungan Permukiman Kumuh Tepian sungai Kecamatan Kolaka. Sulawesi Tenggara. Fakultas teknik Jurusan Arsitektur Universitas Hassanudin

PU Kota Malang, 2014, Profil Kawasan Kumuh di Kota Malang, Laporan tidak diterbitkan

Sadana. S Agus, 2014, Perencanaan Kawasan Permukiman, Jakarta.

Sugiyono, 2010, Statistika untuk Penelitian, Bandung: Alfabeta 
Sulestianson, E., dan Indrajati, P.N., 2014, Penanganan Permukiman Kumuh Dengan Pendekatan Karakteristik dan Faktor Penyebab Kekumuhan (Studi Kasus: Permukiman Kumuh di Kelurahan Tamansari dan Kelurahan Braga), Jurnal Perencanaan Wilayah dan Kota BSAPPK V3N2, dapat diunduh pada http://sappk.itb.ac.id/jpwk2/wp-content/uploads/2014/08/Erick-Sulestianson.pdf

Winarso. Haryo, 2013.Teori Ekistics dan Penataan Ruang di Indonesia, Bab 10 [pdf], (http://repository.usu.ac.id/, diakses tanggal 6 juni 2015 